\title{
Persepsi Akseptor KB Tentang Pemakaian Metode Kontrasepsi Jangka Panjang di Puskesmas Koni Kota Jambi
}

\author{
Arifarahmi ${ }^{\mathbf{1}}$ \\ Program Studi Diploma 3 Kebidanan STIKes Baiturrahim ${ }^{1}$ \\ Email :ami_arifa@yahoo.com
}

\begin{abstract}
Indonesia is the nation with the third largest population in the world. One way to control the population is with the family planning program. The strategy of the implementation of KB program is increase the use of long-term contraceptive methods (MKJP) sterilization (MOW and MOP), IUD and implant. The research used descriptive research; it aimed to determine perception of acceptor $K B$ about use of long-term contraceptive methods at the public health center Koni Jambi city year 2017. Populations were 1.686 people. It used accidental sampling technique i.e. acceptor KB who visit the public health center. Sample for this research was 42 womens. Analyzed univariate was used for statistical analysis. The collecting data used by questionnaire. The result showed 9 acceptors (21\%) used MKJP and 33 acceptors (79\%) choose to use contraceptive non MKJP. 29 acceptors (69\%) have positive perception and 13 acceptors (31\%) have negative perception about use of longterm contraceptive methods. It concluded that there are many acceptor more choose and use contraception non MKJP, it suggested to increase promotion in conducting counseling about contraception to increase awareness of acceptor for themselves especially MKJP contraceptives.
\end{abstract}

\section{Keywords: Perception, Acceptor, Longterm Contraceptive Method}

\section{PENDAHULUAN}

Bangsa Indonesia merupakan Bangsa dengan jumlah penduduk terbanyak ke tiga di dunia, ini merupakan sebuah tantangan bagi pemerintah yang besar yaitu bagaimana upaya mewujudkan cita-cita luhur suatu Bangsa yakni membawa rakyatnya dalam kesejahteraan (Setyaningrum, 2016).

Program KB sebagai salah satu kebijakan pemerintah dalam bidang kependudukan, memiliki implikasi yang tinggi terhadap pembangunan kesehatan, oleh karena itu program $\mathrm{KB}$ memiliki posisi strategis dalam upaya pengendalian laju pertumbuhan penduduk(Suratun, 2008).

Pelayanan keluarga berencana merupakan alasan utama yang diperlukan untuk mencegahan kematian dan kesakitan ibu, membebaskan wanita dari rasa khawatir terhadap terjadinya kehamilan yang tidak diinginkan, terjadinya gangguan fisik atau fisiologik akibat tindakan abortus yan tidak aman serta tuntutan perkembangan sosial terhadap status peningkatan perempuan dimasyarakat. Banyak wanita mengalami kesulitan dalam menentukan pilihan jenis kontrasepsi. Hal ini dikarenakan terbatasnya metode yang tersedia, ketidaktahuan mereka tentang persyaratan dan keamanan metode kontrasepsi yang akan digunakan, status kesehatan, efek samping potensial, konsekuensi kegagalan atau kehamilan yang tidak diinginkan, besar keluarga yang direncanakan, persetujuan pasangan, biaya, bahkan norma budaya lingkungan dan orang tua.Gerakan KB Nasional selama ini telah berhasil mendorong peningkatan peran serta masyarakat dalam membangun keluarga kecil yang makin mandiri. Keberhasilan ini mutlak harus diperhatikan bahkan terus ditingkatkan karena pencapaian tersebut belum merata, sementara ini kegiatan Keluarga Berencana masih kurang dalam penggunaan Metode Kontrasepsi Jangka Panjang (BKKBN, 2012).

Laporan BKKBN tahun 2016, menunjukkan metode KB hormonal yaitu metode kontrasepsi suntikan dan pil merupakan metode kontrasepsi yang paling dominan digunakan oleh peserta KB DI Povinsi Jambi. Pencapaian pengguna KB aktif di fasilitas kesehatan Kota Jambi sebanyak 68.008 peserta. Dari jumlah tersebut alat kontrasepsi MKJP yang digunakan antara lain, metode IUD sebanyak 5.246 peserta $(7,71 \%)$, metode kontrasepsi implant sebanyak 3.389 peserta (4,98\%), metode MOW sebanyak 1661 peserta $(2,4 \%)$, metode MOP sebanyak 137 orang $(0,20 \%)$. Sedangkan metode non MKJP seperti suntikan sebanyak 31.212 peserta $(45,8 \%)$, metode kontrasepsi pil sebanyak 
23.369 peserta $(34,5 \%)$, metode kontrasepsi kondom sebanyak 2994 peserta $(4,4 \%)$ (BKKBN Prov Jambi, 2016).

Strategi dari pelaksanaan program KB sendiri seperti tercantum dalam Rencana Pembangunan Jangka Menengah (RPJM) tahun 2015-2019 adalah meningkatkan penggunaan metode kontrasepsi jangka panjang yaitu IUD (Intra Uterine Device), implant (susuk)dan sterilisasi (MOW dan MOP) (Puslitbang, 2007).

Salah satu syarat yang harus dipenuhi oleh suatu metode kontrasepsi yang baik adalah pemakainnya jangka lama (continuation rate). Alat kontrasepsi MKJP memenuhi syarat kontrasepsi yang baik, karena hanya memerlukan satu kali pemasangan, tidak menimbulkan efek sistematik, ekonomis dan cocok untuk penggunaan secara massal, efektivitas tinggi dan reversible (BKKBN Prov Jambi, 2012).Meskipun program penggunaan alat kontrasepsi jangka panjang sudah masuk dalam berbagai program pemerintah namun angka pencapaian akseptor KB MKJP masih tergolong rendah dibandingkan metode yang lain. Rendahnya penggunaan metode kontrasepsi jangka panjang dapat disebabkan karena beberapa faktor seperti : ketidaktahuan peseta tentang kelebihan metode kontrasepsi jangka panjang, kualitas pelayanan KB dilihat dari segi ketersediaan alat kontrasepsi dan ketersediaan tenaga yang terlatih serta kemampuan medis teknis petugas pelayanan kesehatan, biaya pelayanan metode kontrasepsi jangka panajang yang mahal, adanya hambatan dukungan dari suami dalam pemakaian metode kontrasepsi jangka panjang, dan adanya nilai yang timbul dari adanya persepsi atau keyakinan yang didsarkan kepercayaan dannrma-norma dimasyarakat (Nurcahyanti, 2014).

\section{METODE PENELITIAN}

Penelitian ini di lakukan terhadap akseptor KB di Puskesmas Koni Kota Jambi tahun 2017. Penelitian ini menggunakan penelitian deskriptif. Populasi penelitian adalah akseptor KB tahun 2016 yang berjumlah 1.686 orang. Tekhnik pengambilan sampel adalah accidental sampling, yaitu akseptor KB yang berkunjung ke Puskesmas berjumlah 42 orang. Proses pengumpulan data menggunakan kuesioner, dan analisis data di lakukan secara univariat.

\section{HASIL DAN PEMBAHASAN \\ Karakteristik Akseptor KB}

Tabel 1. Karakteristik Umur Akseptor KB

\begin{tabular}{cccc}
\hline No & $\begin{array}{c}\text { Umur } \\
(\text { Tahun) }\end{array}$ & $\begin{array}{c}\text { Jumlah } \\
\text { Aksptor KB }\end{array}$ & $\begin{array}{c}\text { Persentase } \\
(\%)\end{array}$ \\
\hline 1 & $20-35$ & 20 & 47,6 \\
2 & $>35$ & 22 & 52,4 \\
& Jumlah & 42 & 100 \\
\hline
\end{tabular}

Tabel 2. Karakteristik PendidikanAkseptor KB

\begin{tabular}{clcc}
\hline No & \multicolumn{1}{c}{ Pendidikan } & Jumlah & $\begin{array}{c}\text { Persentase } \\
(\%)\end{array}$ \\
\hline 1 & Tidak Sekolah & 1 & 2,4 \\
2 & SD & 5 & 11,9 \\
3 & SMP & 11 & 26,2 \\
4 & SMA/SMK & 19 & 45,2 \\
5 & Perguruan Tinggi & 6 & 14,3 \\
& Jumlah & 42 & 100 \\
\hline
\end{tabular}

Tabel 3. Karakteristik Pekerjaan Akseptor KB

\begin{tabular}{llcc}
\hline No & Pekerjaan & Jumlah & Persentase (\%) \\
\hline 1 & IRT & 22 & 52,4 \\
2 & Swasta & 12 & 28,6 \\
3 & Wiraswasta & 5 & 11,9 \\
4 & PNS & 2 & 4,8 \\
5 & Guru & 1 & 2,4 \\
Jumlah & 42 & 100 \\
\hline
\end{tabular}

\section{Pemakaian Metode Kontrasepsi Jangka Panjang (MKJP)}

\author{
Diagram 1 \\ Akseptor KB Berdasarkan Pemakaian \\ MKJP
}

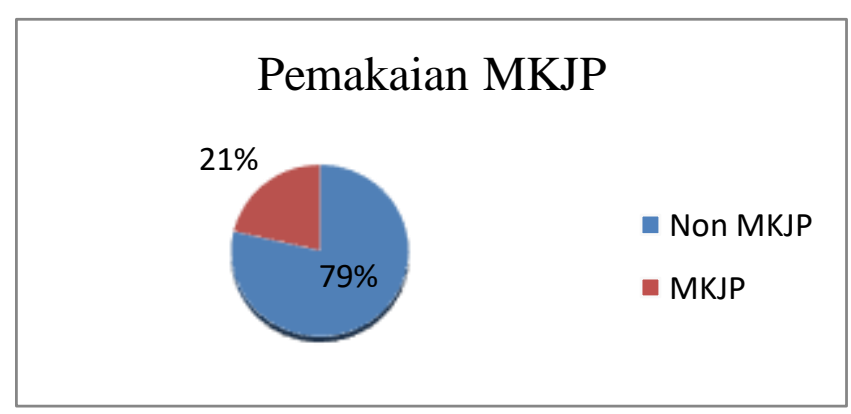


Tabel 4. Distribusi Penggunaan Alat Kontrasepsi

\begin{tabular}{|c|c|c|c|c|c|c|}
\hline \multirow{2}{*}{ No } & \multicolumn{3}{|c|}{ MKJP } & \multicolumn{3}{|c|}{ Non MKJP } \\
\hline & KB & $\mathrm{f}$ & $\%$ & KB & $\mathrm{F}$ & $\%$ \\
\hline 1 & IUD & 5 & 11,9 & Suntik 1 bulan & 13 & 31 \\
\hline 2 & Implant & 3 & 7,1 & Suntik 3 bulan & 9 & 21,4 \\
\hline 3 & MOW & 1 & 2,4 & Pil KB & 10 & 23,8 \\
\hline 4 & MOP & - & - & Kondom & 1 & 2,4 \\
\hline Jumlah & & 9 & 21,4 & & 33 & 78,6 \\
\hline
\end{tabular}

\section{Persepsi}

Tabel 5. Pernyataan Persepsi Akseptor KB Tentang Pemakaian MKJP

\begin{tabular}{|c|c|c|c|c|c|c|c|c|c|}
\hline \multirow{3}{*}{ No } & \multirow{3}{*}{ Pernyataan } & \multicolumn{8}{|c|}{ Distribusi } \\
\hline & & \multicolumn{2}{|c|}{ STS } & \multicolumn{2}{|c|}{ TS } & \multicolumn{2}{|r|}{$\mathrm{S}$} & \multicolumn{2}{|c|}{ SS } \\
\hline & & $\mathrm{f}$ & $\%$ & $\mathrm{f}$ & $\%$ & $\mathrm{f}$ & $\%$ & $\mathrm{f}$ & $\%$ \\
\hline 1 & $\begin{array}{l}\text { Saya harus mengetahui alat kontrasepsi } \\
\text { apa yang cocok untuk diri saya }\end{array}$ & 0 & 0 & 0 & 0 & 21 & 50 & 21 & 50 \\
\hline 2 & $\begin{array}{l}\text { Saya membutuhkan metode KB dalam } \\
\text { jangka waktu lama dan sedikit efek } \\
\text { samping }\end{array}$ & 0 & 0 & 2 & 4,8 & 27 & 64,3 & 13 & 31 \\
\hline 3 & $\begin{array}{l}\text { Menurut saya setalah AKDR dilepas } \\
\text { maka kesuburan ibu dapat cepat pulih }\end{array}$ & 1 & 2,4 & 17 & 40,5 & 18 & 42,9 & 6 & 14,3 \\
\hline 4 & $\begin{array}{l}\text { Menurut saya metode kontrasepsi } \\
\text { implant dapat digunakan dalam jangka } \\
\text { waktu lama dan tidak mengganggu saat } \\
\text { bersenggama }\end{array}$ & 1 & 2,4 & 15 & 35,7 & 21 & 50 & 5 & 11,9 \\
\hline 5 & $\begin{array}{l}\text { Ada beberapa tokoh masyarakat yang } \\
\text { menyarankan untuk menggunakan } \\
\text { MKJP diantaranya IUD, Implant, } \\
\text { MOW dan MOP }\end{array}$ & 1 & 2,4 & 8 & 19 & 19 & 45,2 & 14 & 33,3 \\
\hline 6 & $\begin{array}{l}\text { Menurut saya metode kontrasepsi } \\
\text { implant adalah kontrasepsi yang mana } \\
\text { dan efektif }\end{array}$ & 1 & 2,4 & 21 & 50 & 15 & 35,7 & 5 & 11,9 \\
\hline 7 & $\begin{array}{l}\text { Menurut saya metode kontrasepsi } \\
\text { IUD/AKDR tidak membuat perubahan } \\
\text { pola haid dan tidak menyebabkan } \\
\text { kegemukan }\end{array}$ & 2 & 4,8 & 16 & 38,1 & 20 & 47,6 & 4 & 9,5 \\
\hline 8 & $\begin{array}{l}\text { Saya ingin menggunakan KB yang } \\
\text { tidak membuat saya harus datang } \\
\text { kepetugas kesehatan setiap bulan } \\
\text { Menurut saya dengan menggunakan }\end{array}$ & 1 & 2,4 & 10 & 23,8 & 21 & 50 & 10 & 23,8 \\
\hline 9 & $\begin{array}{l}\text { MKJP membuat saya tidak harus selalu } \\
\text { mengingat seperti metode KB Pil }\end{array}$ & 13 & 31 & 16 & 38,1 & 0 & 0 & 13 & 31 \\
\hline 10 & $\begin{array}{l}\text { Menurut saya metode konrasepsi yang } \\
\text { tepat digunakan oleh pasutri yang tidak } \\
\text { ingin menambah lagiyaitu metode } \\
\text { kontap (sterilisasi) }\end{array}$ & 0 & 0 & 1 & 2,4 & 32 & 76,2 & 9 & 21,4 \\
\hline
\end{tabular}

Pernyataan yang mendapat hasil persepsi positif terbanyak yaitu pernyataan bahwa responden harus mengetahui alat kontrasepsi yang cocok untuk dirinya yaitu $100 \%$. Sedangkan untuk pernyataan negatif terbesar yaitu pernyataan bahwa metode kontrasepsi implant adalah alat kontrasepsi yang aman dan efektif sebesar 52,4\%. Maka diketahui hasil analisis persepsi akseptor KB tentang pemakaian metode kontrasepsi jangka panjang
(MKJP) seperti yang terdapatpada diagram 2berikut : 
Diagram 2

Persepsi Akseptor KB Tentang Pemakaian MKJP

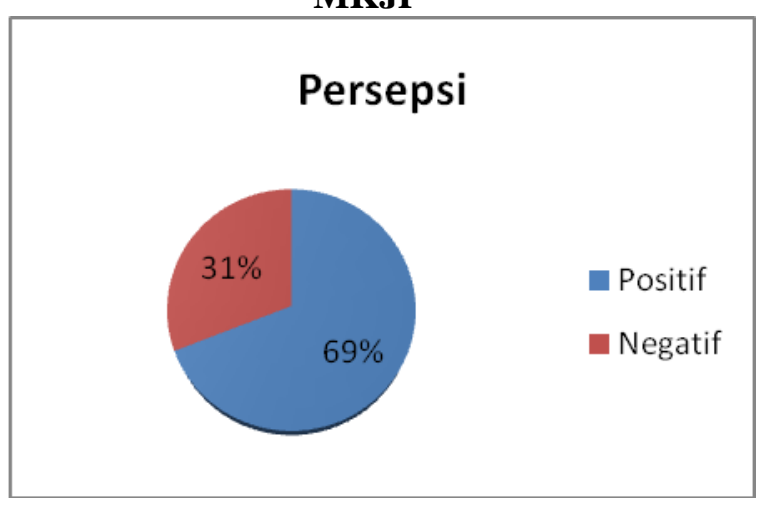

\section{Gambaran Pemakaian Metode Kontrasepsi Jangka Panjang (MKJP)}

Hasil penelitian tentang pemakaian metode kontrasepsi jangka panjang (MKJP) menunjukkan bahwa sebanyak 33 akseptor (79\%) memilih alat kontrasepsi Non MKJP dan 9 akseptor (21\%) memilih alat kontrasepsi MKJP di Puskesmas Koni Kota Jambi tahun 2017.

Metode kontrasepsi jangka panjang (MKJP) adalah metode kontrasepsi yang dikenal efektif karena dapat memberikan perlindungan dari resiko kehamilan 3 tahun hingga 10 tahun yang terdiri dari MOW, MOP, IUD dan Implant.Sedangkan non metode kontrasepsi jangka panjang (Non MKJP) adalah metode kontrasepsi yang digunakan dengan memberikan perlindungan yang sementara atau waktu yang sebentar dengan jangka waktu beberapa bulan atau hari seperti kontrasepsi Suntikan, Pil dan Kondom (BKKBN, 20112).Tingginya Pemilihan Non Metode Kontrasepsi Jangka Panjang dipengaruhi oleh pekerjaan responden yang jarang berinteraksi dengan orang lain.

Pekerjaan mempunyai peranan penting dalam mendapatkan informasi tambahan di luar pendidikan formal. Pada ibu-ibu yang bekerja, akan memungkinkan sering berinteraksi dengan orang lain sehingga lebih mudah berbagi informasi sesama teman kerja, sedangkan pada ibu yang lingkup kerjanya hanya dirumah saja tidak dapat berbagi informasi.

Hal ini sesuai dengan teori Notoatmodjo (2010), bahwa pekerjaan memiliki peranan penting dalam menentukan kualitas manusia, pekerjaan memberikan kesenjangan antara informasi kesehatan dan praktek yang memotivasi seseorang untuk memperoleh informasi dan berbuat sesuatu untuk menghindari masalah kesehatan.Selain karena faktor pekerjaan, pemilihan metode kontrasepsi jangka panjang menunjukkan bahwa sebagian besar tidak memilih Metode Kontrasepsi Jangka Panjang juga dipengaruhi oleh pendidikan.

Menurut Notoatmodjo (2007), pendidikan mempengaruhi proses belajar, makin tinggi pendidikan seseorang makin mudah orang tersebut untuk menerima suatu informasi sebaliknya jika rendah pendidikan seseorang maka makin sulit orang tersebut untuk menerima suatu informasi.Selain faktor pekerjaan dan pendidikan, rendahnya pemilihan metode kontrasepsi jangka panjang juga dipengaruhi oleh umur responden. Umur responden berpengaruh pada pemilihan alat kontrasepsi, umur antara 35 tahun lebih merupakan fase mengakhiri kehamilan yaitu fase tidak ingin hamil lagi, yang diperlukan jika wanita sudah tidak ingin anak lagi.

Menurut Saifuddin (2010), berdasarkan perencanaan keluarga, dapat ditentukan fasefase penggunaan alat kontrasepsi yang ideal. Umur kurang dari 20 tahun merupakan fase menunda kehamilan, diperlukan pada wanita yang menikah dengan umur masih muda, umur antara 20 tahun sampai 35 tahun adalah fase menjarangkan kehamilan dengan cara mengatur jarak kehamilan yang baik yaitu antara 2 sampai 4 tahun, dan umur antara 35 tahun lebih merupakan fase mengakhiri kehamilan yaitu fase tidak ingin hamil lagi diperlukan jika wanita sudah tidak ingin anak lagi.

Oleh karena itu perlu dilakukan konseling atau penyuluhan kepada masyarakat mengenai metode kontrasepsi jangka panjang (MKJP) yang lebih tepat untuk mengatur jarak kehamilan, mengakhiri kehamilan bahkan mengatur persalinan oleh tenaga kesehatan seperti bidan, melakukan pendekatan budaya dan tokoh masyarakat sehingga penggunaan metode kontrasepsi jangka panjang seperti MOW, MOP, IUD dan Implant dapat ditingkatkan dan bukan merupakan sesuatu hal yang dianggap tabu dan asing untuk dipilih dan digunakan sehingga mudah diterima dan dimanfaatkan dengan baik oleh masyarakat. 
Gambaran Persepsi Akseptor KB Tentang Pemakaian Metode Kontrasepsi Jangka Panjang (MKJP) di Puskesmas Koni Kota Jambi Tahun 2017

Hasil analisaberdasarkan persepsi akseptor KB tentang pemakaian metode kontrasepsi jangka panjang (MKJP) bahwa sebanyak 29 akseptor (69\%) memiliki persepsi positif dan 13 akseptor (31\%) memiliki persepsi negatif tentang pemakaian metode kontrasepsi jangka panjang (MKJP) di Puskesmas Koni Kota Jambi tahun 2017.

Persepsi negatif yang ditunjukkan oleh akseptor KB yaitu masih banyaknya responden yang menganggap bahwa dengan menggunakan MKJP responden tidak perlu khawatir lagi untuk selalu mengingat seperti halnya kontrasepsi Pil dan masih banyaknya responden yang tidak setuju bahwa kontrasepsi MKJP merupakan metode kontrasepsi yang aman efektif, tidak menganggu pola haid serta tidak mengganggu saat bersenggama.

Hal ini didukung dengan pernyataan langsung oleh responden diluar pernyataan dan pernyataan yang diajukan oleh peneliti yaitu salah satu faktor yang mempengaruhi pemilihan MKJP yaitu masih banyak responden merasa khawatir dan takut untuk menggunakan MKJP karena harus memasukkan kapsul dibawah kulit yaitu kontrasepsi Implant, terdapat kekhawatiran jika kapsul tersebut bergerak menuju ke bagian tubuh yang lain setelah dimasukkan dilengan serta AKDR harus dipasang didalam rahim.

Persepsi adalah suatu proses otomatis yang terjadi dengan sangat cepat dan kadang tidak kita sadari, dimana kita dapat mengenali stimulus yang diterima. Robbin (2003) mendefinisikan persepsi sebagai proses dimana seseorang mengorganisasikan dan menginterpretasikan sensasi yang di rasakan dengan tujuan untuk memberi makna terhadap lingkungannya (Notoatmodjo, 2010).Terdapat beberapa faktor yang mempengaruhi persepsi yaitu faktor internal terdiri dari pengalaman, harapan atau ekpektasi, kebutuhan, motivasi, emosi dan budaya yang melatar belakangi kelompok tersebut.Faktor eksternal dipengaruhi oleh kontras, perubahan intensitas, pengulangan, sesuatu yang baru dan sesuatu yang menjadi perhatian orang banyak. Oleh karena itu untuk mewujudkan persepsi tersebut menjadi suatu perbuatan nyata diperlukan faktor pendukung atau suatu kondisi yang memungkinkan, antara lain adalah fasilitas dan faktor pendukung seperti dukungan keluarga dan petugas kesehatan sehingga dengan adanya pengetahuan dan dukungan keluarga akan membentuk persepsi positif responden

\section{SIMPULAN}

1. Sebanyak 9 akseptor (21\%) memilih menggunakan metode kontrasepsi jangka panjang (MKJP) dan 33 akseptor (79\%) lebih memilih menggunakan metode kontrasepsi Non MKJP.

2. Sebanyak 29 akseptor (69\%) memiliki persepsi positif dan 13 akseptor (31\%) memiliki persepsi negatif tentang pemakaian metode kontrasepsi jangka panjang.

\section{DAFTAR PUSTAKA}

Aniek, S. 2014. Kesehatan Reproduksi dan Pelayanan Keluarga Berencana.In Media. Bogors

Arikunto, S. 2010. Prosedur Penelitian Suatu Pendekatan Praktek, Rineka Cipta. Jakarta

BKKBN.2007. Pembangunan Kependudukan dan Keluarga Berencana.PT. Bina Pustaka Sarwono Prawirohardjo. Jakarta

2012. Buku Panduan Praktis Pelayanan Kontrasepsi. Bina Pustaka Sarwono Prawirohardjo. Jakarta

Dewi. 2014. Rendahnya Keikutsertaan Pengguna Metode Kontrasepsi Jangka Panjang pada Pasangan Usia Subur. Jurnal. Universitas Airlangga

Dinas Kesehatan Kota Jambi. 2015. Laporan Dinas Kesehatan Kota Jambi Tahun 2015 dan 2016

DPPKB. 2016. Laporan Dinas Pengendalian Penduduk dan Keluarga Berencana. Jambi

Hidayat, A, A. 2008.Metode Penelitian Kebidanan dan Tekhnik Analisa Data.Salemba Medika. Jakarta

Koes, I. 2014. Pelayanan Keluarga Berencana. Alfabeta. Bandung

Manuaba.2010. Ilmu Kebidanan Penyakit Kandungan dan Keluarga Berencana untuk Pendidikan Bidan Edisi 2.EGC. Jakarta

Notoatmodjo. S. 2007.Kesehatan Masyarakat Ilmu dan Seni. Rineka Cipta. Jakarta 
2010. Promosi Kesehatan dan Aplikasi Edisi Revisi. Rineka Cipta. Jakarta

2012. Metodologi Penelitian Kesehatan. Rineka Cipta. Jakarta

Setiyaningsih, E. 2016. Keluarga Berencana. Trans Info Media. Jakarta

Prawirohardjo, S. 2009. Ilmu Kandungan. Penerbit Yayasan Bina Pustaka Sarwono Prawirohardjo. Jakarta

Puslitbang.2007. KeluargaBerencana untuk Keluarga Bahagia. Jakarta

Riyanto. 2011. Aplikasi Metodologi Penelitian Kesehatan. Nuha Medika. Yogyakarta

Saifudin, AB. 2010. Buku Panduan Praktis Pelayanan Kontraepsi. YBPSP.Jakarta

Setiyaningsih, E. 2016.Keluarga Berencana. Trans Info Media. Jakarta

Sibagariang. E. 2016. Kesehatan Reproduksi dan Keluarga Berencana. Nuha Medika. Jakarta

Sulistyawati, A. 2014.Pelayanan Keluarga Berencana. Salemba Medika. Jakarta

Suratun.2008. Pelayanan Keluarga Berencana dan Pelayanan Kontrasepsi.Trans Info Media. Jakarta

Wawan, A. 2010.Teori Pengukuran Pengetahuan, Sikap dan Perilaku Manusia. Nuha Medika. Yogyakarta

Setyaningsih, E. 2016.Keluarga Berencana. Trans Info Media.jakarta

Sulistyawati, A. 2014.Pelayanan Keluarga Berencana. Salemba Medika. Jakarta

Wawan, A. 2010.Teori Pengukuran Pengetahuan, Sikap, dan Perilaku Manusia. Nuha Medika. Yogyakarta 